\title{
O naturalismo e suas dispersões em filmes brasileiros dos anos 2000
}

Bruno Leites

Doutor; Universidade Federal do Rio Grande do Sul, Porto Alegre, RS, Brasil bruno.leites@ufrgs.br

\begin{abstract}
Resumo
O naturalismo literário é uma estética frequentemente repelida quando se trata de pesquisar naturalismo e realismo no cinema. Neste trabalho, faço uma abordagem alternativa, recuperando as suas principais características para compreender uma onda de filmes brasileiros dos anos 2000. Ao longo da década, uma série de filmes atualizou essas características, dentre as quais destaco o objetivo de fazer estudos de realidades periféricas esgotadas pela crise de modelos de civilização; a procura por doenças profundamente impregnadas nessas regiões; a recorrência do elemento trágico, da entropia e/ou da pulsão de morte; uma estética de excessos, com crueldade, sensação e sensacionalismo. Essas características reúnem-se em filmes naturalistas, mas se dispersam ao longo da década, mostrando que as premissas naturalistas deixaram de ser atrativas como projeto estético e político com o passar dos anos. Finalmente, reitero a pertinência e a necessidade de colocar o problema da imagem e do naturalismo para além da submissão extrema e caricata ao paradigma da transparência.
\end{abstract}

\section{Palavras-chave}

Naturalismo. Imagem. Cinema brasileiro. Literatura. Pulsão de morte.

\section{Introdução}

O termo naturalismo recorre em análises de imagem, normalmente associado à mimesis e às estéticas da transparência. Essa recorrência coloca o naturalismo como episódio dentro de um dualismo essencial entre artes da transparência e artes da opacidade, dualismo que permite tecer análises diacrônicas em múltiplos campos, como cinema, literatura, arte e teoria da mídia. Yves Chevrel (1993) reconhece a importância dessa tendência trans-histórica no entendimento do naturalismo. Entretanto, alerta-nos o autor, 
não devemos esquecer que o naturalismo é também um "período-conceito" que se disseminou na segunda metade do século XIX (CHEVREL, 1993, p. 12-16). Tal "períodoconceito" articula questões estéticas e políticas do mundo moderno que posteriormente se desdobrariam no século XX e na contemporaneidade. É com essa premissa que encaminho a problematização deste trabalho, no qual pretendo analisar o naturalismo no cinema brasileiro dos anos 2000 .

As imagens referidas neste trabalho são aquelas que primeiro me provocaram a recuperar as teses naturalistas. Elas são provenientes de filmes brasileiros dos anos 2000, cuja análise demonstra um movimento geral de interesse e posterior dispersão do projeto naturalista ao longo da década. Ali vemos filmes naturalistas (Latitude zero, Amarelo manga, Contra todos, Baixio das bestas); outros que vão até o naturalismo, mas para dispersá-lo (Árido movie, Deserto Feliz); outros que se aproximam de traços naturalistas, no entanto por meio de diversificados desdobramentos, como a tragicidade cotidiana (Através da janela), o policial noir ( $O$ invasor) e a comédia abjeta ( $O$ cheiro do ralo); e outros, ainda, que podemos aproximar do debate naturalista seguindo a sugestão da "imagem-pulsão cíclica", de Gilles Deleuze (1985, p. 157-177) (Cronicamente inviável, Quanto vale ou é por quilo?).

Recentemente, penso que houve uma retomada no interesse pelo naturalismo literário, com trabalhos que, de modo geral, não se contentam em colocá-lo como extremo ingênuo e positivista do realismo. Essa impressão está calcada nas publicações de Yves Chevrel (1993) e David Baguley (1990); no artigo de Keith Newlin (2011a) que inclui uma descrição da retomada de interesse no naturalismo literário estadunidense; no trabalho de Fredric Jameson (2015), que busca pensar o realismo e o naturalismo como a tensa relação entre afeto e narrativa, para além da categoria de mimesis; nas coletâneas lançadas recentemente com trabalhos diversificados sobre o naturalismo, no Brasil (GUINSBURG; FARIA, 2017) e nos Estados Unidos (NEWLIN, 2011b); em vários artigos e livros de autores brasileiros acerca do naturalismo, do brutalismo e dos realismos, como Ana Chiara (2012), Antonio Carlos Santos (2011), Beatriz Jaguaribe (2007), Karl Erik Schøllhammer (2013) e Leonardo Mendes e Renata Vieira (MENDES; VIEIRA, 2012).

Gostaria de destacar, ainda, que o naturalismo, desde uma certa filosofia contemporânea, tem sido compreendido como estudo e prática da matéria bruta e da pulsão de morte. Gilles Deleuze é um autor que se interessou pela obra de Émile Zola ao longo da sua trajetória e propôs o conceito de imagem-pulsão para entender o naturalismo no cinema. Sumariamente, podemos dizer que os realizadores de imagens-pulsão são "médicos da civilização", que fazem estudos de determinados espaços evidenciando doenças profundamente impregnadas. Segundo Deleuze (1985), naturalismo e pulsão de morte estão 
intrinsecamente ligados, sendo o naturalismo o projeto por excelência na literatura e no cinema de inserção da pulsão de morte como modo de ver o mundo. (DELEUZE, 1985, p. 157-177).

Penso que a abordagem de Deleuze (1985) está em relação com aquela de Rancière (2005). Para tecer a sua conhecida e veemente crítica à noção de modernismo, Rancière (2005) reavalia a importância do romance realista e naturalista do século XIX ${ }^{1}$. Em Rancière (2009), a marca do romance do século XIX é a "ilusão da vontade", que se interessa pela força da matéria bruta em detrimento da racionalidade e da vontade. Essa tendência em arte produz, para Rancière (2009), um "inconsciente estético", que antecede e fundamenta o "inconsciente psicanalítico" e o conceito de pulsão de morte (RANCIÈRE, 2009).

\section{Naturalismo literário, uma herança embaraçosa?}

Conforme atestam Aumont e Marie (2003, p. 210-211), não houve no cinema uma escola que reivindicasse as teses naturalistas. De modo geral, no cinema o naturalismo é retomado como um sinônimo ou como um episódio da transparência do aparato técnico. Nesse sentido, destaco a abordagem de Xavier (2005, p.41), que associa naturalismo e cinema clássico hollywoodiano surgido a partir de 1914.

Na verdade, o naturalismo literário parece antes ser uma herança embaraçosa do que uma estética a ser retomada. É relevante que muitos autores, inclusive Xavier (2005), apressem-se para marcar a diferença do naturalismo do cinema para um outro, o da literatura, de Émile Zola:

O uso do termo naturalismo não significa vinculação estrita com um estilo literário específico, datado historicamente, próprio a autores como Émile Zola. Ele é aqui tomado numa acepção mais larga, tem suas intersecções com o método ficcional de Zola, mas não se identifica inteiramente com ele. (XAVIER, 2005, p. 41).

Xavier (2005) não tece uma oposição entre o naturalismo do cinema e o da literatura, mas vê-se impelido a demarcar uma distância entre ambos para melhor situar o seu projeto. Stam (2013) produz estratégia correlata para estabelecer uma demarcação entre naturalismo e realismo, tentando reduzir aquele a uma emergência restrita e datada no

\footnotetext{
1 “O pulo para fora da mímesis não é em absoluto uma recusa da figuração. E seu momento inaugural foi com frequência denominado realismo, o qual não significa de modo algum a valorização da semelhança, mas a destruição dos limites dentro dos quais ela funcionava. Assim, o realismo romanesco é antes de tudo a subversão das hierarquias da representação (o primado do narrativo sobre o descritivo ou a hierarquia dos temas) e a adoção de um modo de focalização fragmentada, ou próxima, que impõe a presenta bruta em detrimento dos encadeamentos racionais da história." (RANCIÈRE, 2005, p. 35).
} 
tempo, e inserindo o debate do realismo no cinema na tradição desse último, tido como profundo e democratizante.

Os críticos literários distinguiam entre esse realismo profundo e democratizante e um "naturalismo" reducionista raso e obsessivamente verista - cuja manifestação mais conhecida são os romances de Émile Zola - que espelhava suas representações humanas nas ciências biológicas. (STAM, 2013, p. 30).

André Bazin (1971) também sente necessidade de usar a diferenciação como estratégia teórica para definir o neorrealismo italiano. Para Bazin (1971), havia uma diferença de forma e conteúdo entre o neorrealismo e os realismos anteriores, dentre os quais o naturalismo aparece como exemplo privilegiado:

O neorrealismo contrasta com a estética realista que o precedeu e em particular com o naturalismo e o verismo, na medida em que seu realismo não se preocupa tanto com a escolha dos temas quanto com um modo particular de considerar as coisas. (BAZIN, 1971, p. 97, tradução nossa).

Assim, o naturalismo literário, antes de ser uma influência que os teóricos pretendem explorar, é uma herança da qual é preciso desde logo se desembaraçar. Isso vale para apropriações tão distintas quanto aquelas de Bazin (1971), contrapondo o naturalismo ao realismo fenomenológico, e de Xavier (2005), diferenciando-o da linguagem clássica de Hollywood.

Fredric Jameson (2015, p. 2), ao escrever sobre o realismo, diagnosticou que ele aparece majoritariamente preso a oposições, inclusive nas querelas internas de definições de tendências de realismo e na clássica oposição entre realismo e naturalismo: realismo contra modernismo; realismo contra naturalismo; realismo socialista contra realismo burguês. No âmbito do cinema, parece que o naturalismo também é absorvido por oposições, notadamente como o lado reverso de estéticas a serem consolidadas, constituindo uma espécie de herança embaraçosa. Nesse sentido, este trabalho toma via alternativa, apostando no interesse do projeto naturalista advindo da literatura para a análise de imagens e compreensão de um importante cinema brasileiro dos anos 2000.

\section{Características gerais do naturalismo}

O naturalismo é constantemente lembrado e muitas vezes definido por seus temas de interesse. Embora considere que a análise temática é importante, penso que, pelo menos 
no caso do naturalismo, ela é a decorrência de certos pressupostos que constituem as características gerais desse universo estético, filosófico e político. Becker (2010) e Baguley (1990, p. 204-223) fizeram um inventário dos temas naturalistas: o alcoolismo, a prostituição, o adultério, a falência, o estupro, o incesto e o fetichismo, entre outros. Não devemos nos surpreender de encontrá-los em abundância nos filmes brasileiros dos anos $2000^{2}$. Os temas são desdobramentos das características gerais, que serão apresentadas adiante sob três eixos: estudo de realidade cotidiana e doença de civilização; pulsão de morte, entropia e/ou tragicidade; sensação e sensacionalismo.

Em primeiro lugar, ressalto que o naturalismo se realiza como o estudo de uma determinada realidade, quase sempre contemporânea à obra e muito bem delimitada no espaço e no tempo, além disso com baixa incidência de alegorias e simbolizações. A clássica definição de naturalismo, proposta por Émile Zola (2004), insere esse projeto no contexto dos estudos científicos de questões contemporâneas, reivindicando para si a cientificidade do social. A monumental série de Zola, Les Rougon-Macquart, possui o elucidativo subtítulo de História natural e social de uma família sob o Segundo Império. No Brasil, o naturalismo dedicou-se aos chamados estudos de temperamento (A carne, Bom-crioulo, $O$ mulato, $A$ normalista), mas também aos estudos de espaços típicos ( $O$ cortiço, Casa de pensão, A luta).

Nos filmes brasileiros, a presunção de cientificidade é um elemento que não permanece; no entanto, o projeto de fazer obras como estudos de realidades contemporâneas muito bem delimitadas no tempo e no espaço é uma constante. Nesse sentido, as palavras de Cláudio Assis (2011) são esclarecedoras. Ele revela que, após transitar pelo Sertão e pela Zona da Mata, decidiu que esta tinha mais interesse como objeto de conhecimento para realizar Baixio das bestas:

A gente pensou muito até em filmar no Sertão, pesquisamos, fomos ao Sertão e tal. E a gente percebeu que o Sertão... ele tem melhores condições até que a Zona da Mata. [...]. Tá no litoral, mas tá fodido. Porque são 500 anos de monocultura da cana de açúcar, entendeu? E que não se libertou ainda, porque é monocultura, porque fode a terra, porque ela não planta comida de subsistência, então ela não vai ter nada pra ninguém. É a cana, é o sugar blues, como dizem os americanos. É a merda, é o câncer, entendeu? E esse câncer impregna nas pessoas também. (ASSIS, 2011a).

Nos filmes naturalistas, Assis e os demais realizadores atribuem importância aos espaços, às vezes por meio de planos longos e sem movimento, que fazem a imagem aproximar-se de quadros naturalistas (Baixio das bestas, Latitude zero, planos documentais

0 alcoolismo é tema em Latitude zero; a prostituição em Baixio das bestas, Deserto feliz, $O$ cheiro do ralo; o adultério em Contra todos; a falência em $O$ cheiro do ralo; o estupro em Latitude zero, Contra todos, Baixio das bestas, Deserto feliz; o incesto em Baixio das bestas; o fetichismo em Amarelo manga, $O$ cheiro do ralo, Baixio das bestas. 
no final de Amarelo manga); às vezes por meio de longos deslocamentos de câmera e personagem, que produzem uma imersão no espaço nos filmes (Contra todos, Amarelo manga, $O$ invasor). Quanto aos deslocamentos, destacam-se por serem circulares em torno de centros, que funcionam como epicentros da doença e da miséria (o hotel em Amarelo manga, a casa de subúrbio em Contra todos, a pequena comunidade em Baixio das bestas) ${ }^{3}$.

Figura 1 - Quadro naturalista em Baixio das bestas

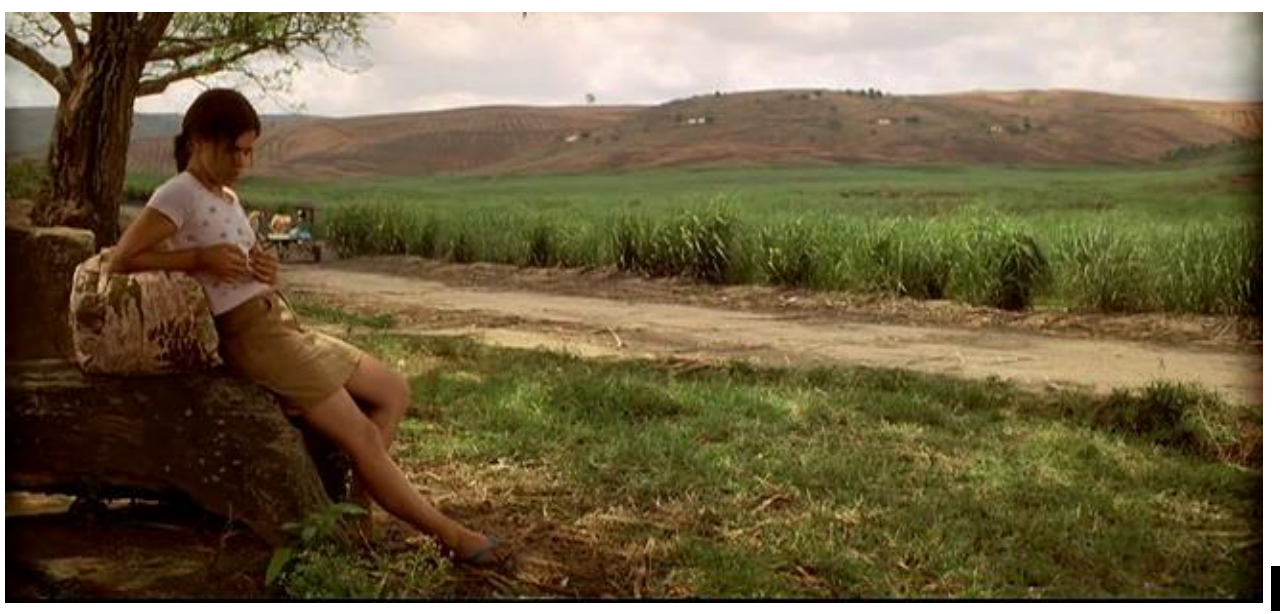

Fonte: Baixio das bestas (2006).

Figura 2 - Quadro naturalista em Latitude zero

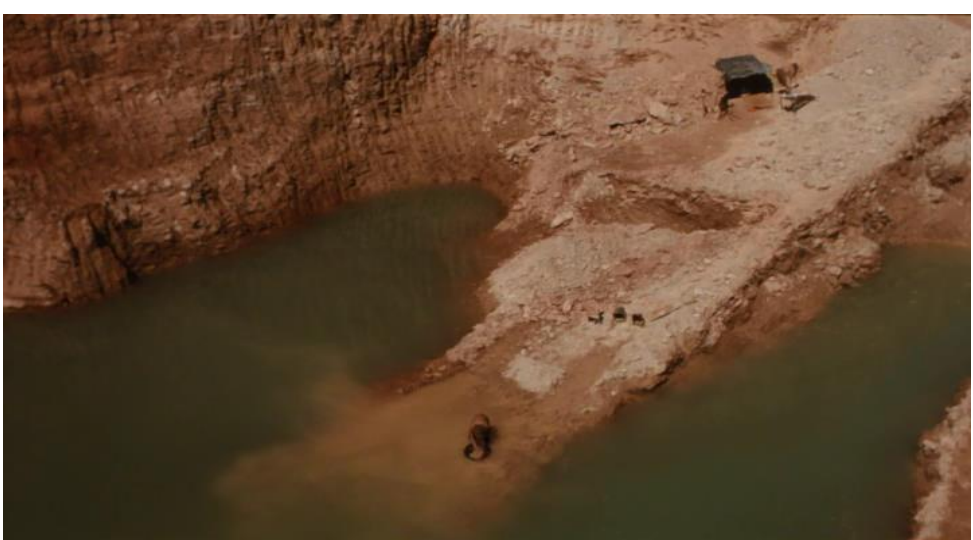

Fonte: Latitude zero (2000).

0 estudo de realidade faz-se à procura de uma doença impregnada, normalmente dispersa, no entanto eficaz no processo de destruição das relações no espaço. As imagens foram utilizadas para materializar metaforicamente e plasticamente essa instância perversa, o que gerou momentos simplórios, como as metáforas do buraco e do ralo para expressar o retorno à superfície das "merdas do mundo" (Baixio das bestas, o cheiro do ralo). Mas houve

\footnotetext{
Tanto quanto os quadros naturalistas, os deslocamentos nesses filmes revelam também a atualização de uma célebre tese naturalista: a indissociabilidade entre o meio e o personagem. Quando os deslocamentos rompem com os espaços centrados na doença (meios), como em Deserto feliz, os personagens estão aptos a entrar em novos encontros, o que produz uma dispersão do naturalismo.
} 
também momentos de beleza plástica, como aquele em que a câmera em contra-plongée direciona-se para as nuvens que passam, enquadrando a meio caminho o prédio da usina em degradação, com imagem em preto e branco e granulada, ao passo em que, em voz over, o narrador-poeta recita acerca da inevitabilidade da ação destrutiva do tempo ${ }^{4}$. A imagem sintetiza plasticamente a insuficiência da construção humana e histórica (usina) frente à ação entrópica do tempo (nuvens).

Figura 3 - Plasticidade e ação destrutiva do tempo em Baixio das bestas

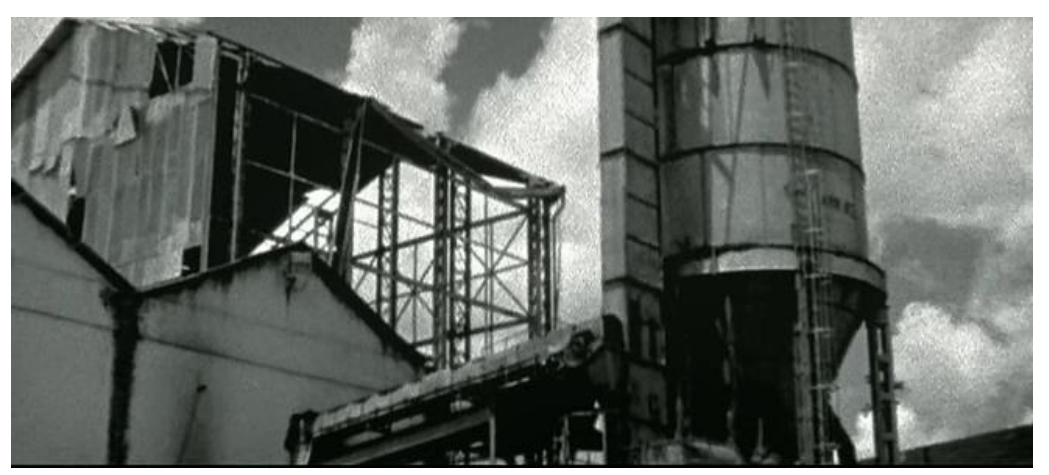

Fonte: Baixio das bestas (2006).

Os realizadores tiveram dificuldades para dar nomes ao elemento destrutivo. 0 vocabulário da doença foi um dos principais recursos, utilizado tanto em entrevistas quanto em pequenas teses inseridas nos próprios filmes, uma prática comum no naturalismo literário. Outros universos de termos também foram utilizados, tais como o da escatologia (variações a respeito da merda) e o da pulsão de morte (violência interna, tendência à destruição). Nos filmes, vemos repetidos momentos de teses sobre o incomensurável da degradação, proferidos por intelectuais, poetas, religiosos, comentadores populares, personagens principais ou secundários, figuras de autoridade duvidosa que teorizam sobre a inviabilidade da condição humana. De modo geral, destaca-se o ato de dar nomes e formular teses acerca de algo tão profundo que escapa continuamente à representação.

0 estudo em busca da doença impregnada conduz a uma estética que pode ser compreendida como entrópica, trágica e/ou típica da pulsão de morte. Longe de ser um elemento secundário, existe nesse ponto uma característica que deve ser tomada como constitutiva do naturalismo. 0 realizador naturalista não apenas se interessa por fazer estudos de realidades doentias, ele vê em quaisquer realidades a ação de uma doença impregnada. Assim, não é o real em si contaminado que define essa característica, mas a conjunção entre o que o real pode oferecer e o que a visão do realizador está condicionada a observar.

\footnotetext{
4 “Outrora, aqui, os engenhos; recortavam a campina. Veio o tempo e os engoliu; e ao tempo engoliu a usina. Um ou outro ainda há quem diga; que o tempo vence no fim: um dia ele engole a usina; como engole a ti e a mim." (BAIXIO..., 2006, doc. não paginado).
} 
Veremos essa característica em autores de referência sobre o naturalismo. David Baguley (1990) intitula o seu principal livro sobre o naturalismo como $A$ visão entrópica, mostrando em detalhes na obra como essa visão faz-se presente como uma marca constitutiva do movimento. Yves Chevrel (1993, p. 53-76) retoma a ideia de uma tragicidade a todo momento implícita no naturalismo, tragicidade que não é aquela mítica e transcendental, mas que aparece aqui como o lado reverso do cotidiano, sempre à espreita na matéria da vida. Já em Deleuze (1985, p.157-177), o naturalismo remete a uma grande pulsão de morte que produz entropia, violência interna e ciclos sem diferença. Em Rancière (2005; 2009), o naturalismo está inserido no conjunto de romances das "ilusões da vontade", os quais se definem, grosso modo, por aqueles que se interessaram pela força da matéria bruta e sua implicação sobre as "vontades". O romance realista e naturalista do século XIX teria produzido um inconsciente estético, fornecendo as bases para o inconsciente psicanalítico e para o conceito de pulsão de morte em Sigmund Freud (RANCIÈRE, 2005, p. 27-44; 2009, p. 63-77).

Os termos empregados por Chevrel (1993), tragédia e cotidiano, aproximam-se daqueles utilizados por Roberto Moreira (2010) e Tata Amaral (XAVIER; BERNARDET; ABREU; AMARAL, 1999) ${ }^{5}$ para definir os projetos que realizaram em Contra todos e Através da janela ${ }^{6}$. Nesses filmes, a atenção destinada a famílias de periferia revela uma suposta tragicidade à espreita no cotidiano.

A tragicidade manifesta-se nos filmes por meio do que Deleuze (1985, p. 158) chamou de lei ou linha de "maior inclinação" e Baguley (1990, p. 97-119) chamou de "queda". A queda pode ser vertiginosa, de acordo com seus graus de inclinação. Ela pode conduzir à aniquilação literal dos espaços e dos corpos (a sequência final de mortes em Contra todos, o incêndio do restaurante em Latitude zero, o assassinato do mercante capitalista em $O$ cheiro do ralo). É comum também que, após a queda, um ciclo tão ou mais perverso do que o anterior seja relançado. Em Contra todos, na última cena do filme vemos o personagem que foi o catalizador da tragédia na narrativa recomeçar tudo outra vez, agora se aproximando de outra família. Em Amarelo manga, uma das cenas finais redobra a inicial e mais um dia recomeça, igual ao que passou, como afirma a personagem olhando para a câmera. Em Baixio das bestas, a última cena recoloca dois personagens comentando fatos do cotidiano; eles discutem sobre a continuidade da cultura da cana e fazem vista grossa para

\footnotetext{
Este texto, publicado em 1999 no segundo número da revista Estudos de cinema, é uma compilação com as comunicações dos quatro autores em evento promovido pelo Centro de Estudos de Cinema (CEC), vinculado ao Programa de Estudos PósGraduados em Comunicação e Semiótica da Pontifícia Universidade Católica de São Paulo (PUC-SP).

6 Sobre Através da janela, Tata Amaral afirma: “Como o Jean-Claude bem definiu aqui, na tragédia não se toma cafezinho. Mas nesse filme que estamos fazendo, se faz cafezinho e se lava roupa.”. A realizadora complementa: “[...] a dificuldade de se trabalhar com o trágico e o prosaico é imensa." (XAVIER; BERNARDET; ABREU; AMARAL, 1999, p. 94).
} 
as violências que aconteceram na comunidade; um deles demonstra interesse em ter a menina para si, a mesma que foi repetidamente abusada ao longo da narrativa.

Até aqui expus as características do naturalismo relacionadas ao estudo de realidade e à pulsão de morte. É imprescindível, todavia, mencionar a dimensão de sensação e de sensacionalismo ${ }^{7}$ que desde sempre pautou esse projeto. 0 interesse pela força da matéria bruta não se reduz às teses sobre instintos de personagens, mas avança para um estilo de escrita e de imagem que pretende interpelar sensorialmente o leitor e o espectador ${ }^{8}$. Por isso, penso que é correto afirmar, com Keith Newlin (2011a), que o naturalismo é inseparável de uma estética do excesso.

Nos filmes brasileiros com características naturalistas, a aposta na sensação gerou uma estética da crueldade, que, em certos momentos, foi feita procurando diferenciar-se da estética da violência comum em uma tendência do cinema brasileiro na mesma década. 0 projeto mais evidente nesse sentido, além daquele de Cláudio Assis em Amarelo manga, está no filme $O$ invasor. Aquino (2009), roteirista do filme, concebeu a sua Teoria do Monstro com a premissa de que o monstro-violência é mais assustador se permanece escondido. Seria preciso, portanto, fazer um filme sobre a violência, mas que produzisse uma violência não figurativa para não "neutralizar o monstro": "Era uma coisa ideológica quase, de não mostrar a violência, não interessava ficar mostrando graficamente a violência.", relatou Aquino (2009, doc. não paginado).

No mesmo sentido, podemos notar que Cláudio Assis abala-se quando seus filmes são considerados violentos: “Uma hipocrisia! Meus filmes não são violentos. Isso é uma mentira!", afirma (ASSIS, 2011b, doc. não paginado). Para fugir do conceito de violência, Assis utiliza outros termos, como "forte" e "necessário" (ASSIS, 2011b). Quando ele admite utilizar o espectro da violência, delimita uma espécie de violência interna: "A gente tem uma violência nossa, cotidiana, dentro da nossa própria casa [...] Os outros elementos surgem daí, dessa violência dentro de nós" (ASSIS, 2003). É por isso que em Amarelo manga vemos uma coleção de situações cruéis que se distanciam da violência de filmes de ação em ambientação de criminalidade urbana. A crueldade no filme inclui um personagem disparando arma de fogo sobre um corpo já morto; a violência do cotidiano que existe no abate do boi; um alto surto de agressividade, no entanto com quase nulo potencial ofensivo (um pedaço de orelha é arrancado após ataque de fúria e mordida).

\footnotetext{
7 O sensacionalismo visa a produção do choque fácil e figurativo. A sensação visa a produzir um circuito de vibrações corporais não apenas imediato. Ver Deleuze (2007).

8 Em livros naturalistas vemos uma escrita que pretende colocar o leitor em presença, fazendo-o sentir, visualizar, cheirar e ouvir o espaço descrito e o acontecimento narrado.
} 
É claro que certos filmes abusaram da violência gráfica, com destaque para o interesse nos estupros, filmados em primeiros planos de rostos durante os atos (Latitude zero, Contra todos, Deserto feliz), encenados com virtuosidade e procurando a beleza estética (Baixio das bestas). Habitar e desdobrar a linha tênue entre a sensação e o sensacionalismo é, de todo modo, uma das potências do projeto naturalista do século XIX. Ao procurar a brutalidade do corpo, o naturalismo produziu uma vertente vulgar que se atualizou em gêneros de imediatismo corporal, ditos sensacionalistas. No entanto, ele foi também, juntamente com o realismo do século XIX de modo geral, uma investigação da sensação e dos afetos $^{9}$ no confronto com as possibilidades de significação e organização intelectual da matéria bruta do mundo ${ }^{10}$.

\section{Reunião e dispersão de características naturalistas em filmes brasileiros}

A relação dos filmes com o naturalismo ocorre de modo tenso e variado no cinema brasileiro dos anos 2000. A partir das características expostas no item anterior, vou traçar um panorama de reunião e dispersão dessas características. Esse método possibilita analisar com fluidez a influência do naturalismo, permitindo, inclusive, observar que ele vai deixando de ser uma resposta estético-política convincente ao longo da década.

\subsection{Filmes naturalistas}

Primeiramente, é necessário considerar a existência de um grupo de filmes com uma acentuada carga naturalista, motivo pelo qual eles podem ser nominados simplesmente de filmes naturalistas ou neonaturalistas. Nesse grupo, vemos os filmes de Cláudio Assis, Amarelo manga e Baixio das bestas, o de Roberto Moreira, Contra todos, e o de Toni Venturi, Latitude zero. Aqui as características apresentadas no item anterior aparecem de modo concentrado, quais sejam: os filmes apresentam-se como estudo de realidades periféricas nas bordas do capitalismo, definindo um espaço a ser analisado sob o ponto de vista da procura das doenças impregnadas e que determinam a vida dos personagens. Em todos eles, personagens e meios são indissociáveis e os meios determinam os comportamentos dos personagens, que são conduzidos até as situações de bestialidade. Daí as recorrências temáticas, o alcoolismo, os estupros, os assassinatos, a falência da intelectualidade. As

\footnotetext{
É a tese de Jameson: "O que chamamos de realismo será portanto a simbiose da pura forma do storytelling com impulsos de elaboração cênica, descrição e sobretudo investimento afetivo, o que permite que o realismo se desenvolva no sentido de uma existência cênica, que, em realidade, porém secretamente, abomina as temporalidades que constituem a força da fábula ou da narrativa." (JAMESON, 2015, p. 11, tradução nossa).

${ }^{10}$ Como mencionei anteriormente, é a tese de Rancière $(2005,2009)$.
} 
narrativas possuem grandes quedas (Contra todos, Latitude zero, Baixio das bestas) e/ou fazem ciclos de repetições que ecoam a força da doença impregnada (Amarelo manga, Baixio das bestas, Contra todos). Todos eles procuram o desconforto pela imagem, por meio de práticas de sensação ou sensacionalismo, seja a violência despotencializada de Amarelo manga, os estupros graficamente apresentados (Latitude zero, Contra todos) e encenados com virtuosidade em termos de fotografia e desenho do espaço (Baixio das bestas) ${ }^{11}$. De modo geral, existe sempre a associação entre cotidiano e uma força doentia, designada pelo vocabulário da doença, da entropia ou da pulsão de morte.

\subsection{Filmes com traços naturalistas sob influências diversas}

Em outro grupo de filmes, o naturalismo incide com traços desenvolvidos sob influências diversas. Entendo que é o caso de Através da janela, $O$ invasor e $O$ cheiro do ralo. Longe de ser um elemento secundário, o naturalismo aqui é fundamental, mas o veremos em desdobramentos e relações com outras estéticas correlatas.

A vertente cômica desde sempre mereceu destaque no naturalismo e muitas vezes esteve ligada à produção de estereótipos, ao exagero na observação de vícios e ao absurdo que os naturalistas julgavam revelar para além das aparências do mundo civilizado. A ironia é uma marca veementemente destacada por Baguley (1990, p. 120-163) nas suas análises do naturalismo. 0 naturalismo literário brasileiro está repleto de situações que se pretendem cômicas ao revelar o absurdo das situações, como atestam os romances de Aluízio Azevedo, tais como $O$ mulato e $O$ cortiço ${ }^{12}$. $O$ cheiro do ralo prolonga essa vertente do naturalismo cômico, levando os personagens ao exagero e materializando o absurdo que aumenta à medida que a perversão se intensifica. Nesse filme, são marcantes os vários primeiros planos da bunda da personagem e do ralo, bem como a atração que ambos exercem sobre o personagem principal. Vejam-se, por exemplo, a conversa do personagem com a bunda em primeiro plano, e o gesto de reverência quase religiosa que faz ao posicionar o nariz no ralo.

Através da janela é um estudo do trágico sob situações cotidianas em uma região de classe média. 0 filme apresenta uma oposição de espaços. Na casa principal, o jovem e a mãe formam uma família regular. Mas, na casa-cativeiro que fica em frente, o filho revela-se um sequestrador inescrupuloso, a mãe torna-se uma assassina, a moça cordial mostra-se uma manipuladora experimentada. Em suma, ali os personagens revelam o que são para além da

\footnotetext{
${ }^{11}$ As cenas de violação em Baixio das bestas são encenadas como um grande palco, normalmente com fonte de luz que isola o espaço de visibilidade e eventualmente com personagens espectadores colocados à espreita, o que atesta a relação que o filme produz entre violação e espetáculo, bem como a oferta que tenta fazer ao espectador de uma conjugação entre o desconforto e o prazer de olhar (LEITES, 2017, p. 207-211).

12 Sobre o naturalismo cômico na literatura brasileira, ver Mendes e Vieira (2012).
} 
aparência cotidiana. Deleuze (1985, p. 157-177), ao pensar o naturalismo, falou que nas imagens ele apresenta mundos paralelos, ditos mundos originários, em que os personagens são brutos e vivem regulados por pulsões primárias animalescas. Esses mundos aos poucos desarticulam os "meios derivados", o cotidiano, formando uma relação que aparece com clareza em Através da janela.

Em O invasor, os traços naturalistas (estudo de realidade, pulsão de morte, tragicidade, violência sensorial) constam ressignificados pela influência do filme policial noir ${ }^{13}$ e da literatura brutalista. 0 primitivismo da pulsão de morte naturalista não incide como retorno ao inorgânico, embora haja uma associação simbólica entre o personagem invasor e o cão-demônio, conforme argumenta Nagib (2006, p. 168-170). Além disso, $O$ invasor não se interessa pelas margens da civilização, em que supostamente os personagens estariam abandonados em estágio de animalização, mas pelo processo de degradação no coração do sistema, na rede que ele cria e que abrange todos sem exceção.

\subsection{Filmes com traços naturalistas no estilo "imagem-pulsão cíclica"}

Proponho aproximar da problematização naturalista os filmes que Deleuze (1985) chamou de "imagem-pulsão cíclica". Essa imagem parte de uma atualização que Deleuze (1985) indica estar na esteira do "naturalismo espiritualista" de Joris-Karl Huysmans. Após um período junto ao grupo de Zola, Huysmans distancia-se para propor um "naturalismo espiritualista", que não mais se interessa pelas pulsões do corpo e pela linguagem da sensação, mas pelas nevroses mentais e pelo tempo como vetor da decadência. Normalmente, o período de Huysmans que começa em Às avessas (HUYSMANS, 2011) é considerado como uma ruptura com o naturalismo. Entretanto, Deleuze (1985) reúne ambas as tradições, inspirando-se em Zola e Huysmans, para propor o conceito de imagem-pulsão. As imagens-pulsão cíclicas igualmente pretendem revelar doenças em espaços determinados, no entanto explorando a pulsão de morte como geradora de ciclos de tempo, o que difere do retorno ao inorgânico e da bestialidade do naturalismo entrópico.

Os filmes Cronicamente inviável e Quanto vale ou é por quilo? realizam imagenspulsão cíclicas. Os personagens são tipos, muitas vezes caricaturais, e em ambos os filmes vemos uma inevitabilidade no tempo: os personagens podem tentar produzir diferença, mas terminam por repetir uma impotência originária. Para produzir essa impotência originária, Quanto vale ou é por quilo? constrói um mundo paralelo aterrorizante, no qual os personagens negros estão presos em instrumentos de tortura, dentro de um espaço escuro

${ }^{13}$ Sobre o naturalismo como estágio na linha evolutiva que leva ao film noir, ver Philips (2012). 
sem paisagem. Esse mundo paralelo faz a relação entre o Brasil imperial escravocrata e a realidade contemporânea, funcionando como uma imanência ainda presente e incontornável.

Em Cronicamente inviável, destaco a cena em que o realizador desloca o seu personagem narrador e viajante para o ponto mais distante da urbanidade supostamente civilizada e ali julga encontrar a prova da esterilidade congênita do projeto humano, sobrepondo imagem de queimada, trilha fúnebre barroca e texto em voz over que se aproxima da tese freudiana da pulsão de morte ${ }^{14}$. Essa constatação crua da força da pulsão de morte é o motor que faz as situações repetirem-se ao longo de toda a narrativa. 0 filme produz repetições em vários níveis, no espaço e no tempo. Além das repetições, o filme explora as reinvenções. 0 narrador orienta a imagem a apresentar um passado alternativo para a personagem Amanda; depois, faz o mesmo com relação à profissão da personagem. Essas reinvenções, no entanto, não alteram o destino trágico inscrito no tempo. As reinvenções correspondem a situações no tempo, que são ineficazes frente à força maior do tempo trágico.

Ambos os filmes são marcados pela ironia na análise de situações. Em Cronicamente inviável, existe inclusive a figura de um intelectual viajante que conecta as situações na narrativa, agindo sobretudo como comentarista. Esse narrador faz o tipo do intelectual irônico, que, segundo Baguley (1990, p. 134-141), é uma das tendências do naturalismo francês do Grupo de Médan, sob influência da filosofia de Arthur Schopenhauer.

Quando Deleuze (1985) reúne naturalismo espiritualista e naturalismo corpóreo para pensar a imagem-pulsão, ele está apoiando-se em tendências do naturalismo, mas desdobrando também aspectos constitutivos da pulsão de morte, tal como apresentada por Freud. A pulsão de morte produz um retorno ao inorgânico, mas ela também gera ciclos de repetição como forma de diminuir a intensidade da vida orgânica. Julgo produtivo manter a proposição de Deleuze para pensar imagem e naturalismo no cinema brasileiro porque Cronicamente inviável e Quanto vale ou é por quilo? são formas diferentes de articular uma mesma ordem de questões, tais como a pulsão de morte; o uso das repetições; a construção de personagens irremediavelmente sujeitos a forças que os ultrapassam; além da realização de imagens como estudo de realidade, inclusive com a inclusão de personagens teóricos e um estilo documental de mise-en-scène.

\footnotetext{
14 "Afinal sua vida é fundada sobre o desastre, sobre a destruição de qualquer coisa que não foi ele próprio que construiu. Mas o homem não destrói porque é mal. Ele destrói porque não consegue fazer de outro jeito. Ele é tão adaptado à destruição, que se ele destruísse sem respeitar nenhuma regra, ele acabaria se autoaniquilando." (CRONICAMENTE INVIÁVEL, 2000).
} 


\subsection{Filmes com naturalismo em dispersão}

Árido movie e Deserto feliz colocam questões clássicas do naturalismo. No entanto, enfrentam e resolvem essas questões buscando dispersá-lo. Na segunda metade dos anos 2000, para os realizadores do cinema brasileiro, o naturalismo não pareceu tão urgente quanto havia sido no início da década.

No primeiro ato de Deserto feliz, vemos um filme que desenvolve uma série de características naturalistas: o estudo das relações de uma família de interior, em uma região miserável nas bordas da civilização, das quais emergem comportamentos perversos dentro do ambiente familiar, culminando no estupro da personagem principal pelo padrasto, uma cena construída com um primeiro plano no rosto em desespero no momento da violação. Destaca-se, ainda, a indissociabilidade entre meio e personagem, a relação metafórica estabelecida entre personagens e animais rastejantes que habitam o local (o padrasto persegue e trafica animais exóticos) e o ingresso da protagonista na prostituição.

Entretanto, nos dois atos seguintes a personagem rompe com esse ciclo, dissociandose do meio e ingressando em outras relações que a levam a habitar espaços diferentes. A função do deslocamento é fundamental para a dispersão do naturalismo nesse filme: o longo plano que destaca a materialidade do deslocamento em si próprio; o deslocamento da personagem no ônibus, inserido em montagem paralela com outro deslocamento: aquele da mãe, que anda em círculos dentro do meio naturalista em que vive. Nos filmes majoritariamente naturalistas, há múltiplos deslocamentos, que, todavia, servem para reforçar a constituição do espaço (o meio naturalista). Quando o deslocamento serve para romper com o meio, como em Deserto feliz, o que vemos é um deslocamento desnaturalizante, porque é com ele que o naturalismo tenta dispersar a si próprio.

Em Árido movie, o conflito central da narrativa retoma uma questão clássica do naturalismo literário do século XIX. 0 personagem principal é pressionado pela força da hereditariedade a assumir o local de poder do pai que sequer conhecera. Ele vai à pequena localidade após a morte do pai e o conflito instala-se entre a força do sangue, que retoma a crença naturalista na hereditariedade e a força da formação cultural, que induz o personagem a retornar à grande cidade que habita. Para resolver o conflito, o filme recorre a uma imagem de revelação (as palavras do índio no espaço sagrado surtem efeito) e à morte simbólica do personagem em conflito. Assim, morre o personagem como sujeito de hereditariedade, mas renasce o ser de cultura com laços sociais fortalecidos. Em suma, o filme coloca o típico conflito naturalista, que aparece aqui de modo clássico e anacrônico, 
mas opta finalmente pelo outro lado do dualismo que havia criado para si próprio, isto é, o lado da força da cultura sobre a hereditariedade.

Figura 4 - Morte simbólica em câmera subjetiva do personagem naturalista em Árido movie

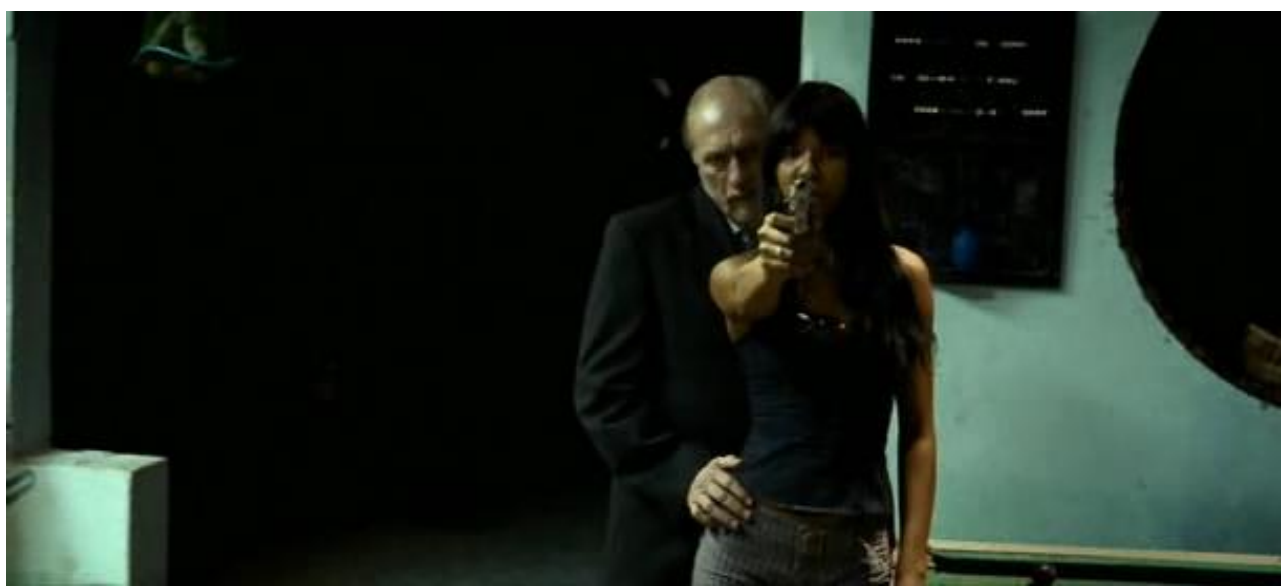

Fonte: Árido movie (2005).

Ressalte-se, portanto, que Deserto feliz e Árido movie, apesar de dispersarem o naturalismo, são profundamente afetados pelas suas premissas. As alternativas que constroem para si próprios são dualismos típicos desse universo. Inclusive, talvez fosse mais adequado falarmos em filmes que tentam dispersar o naturalismo. De todo modo, o embate e a dispersão ocorrem no corpo a corpo interno, um diálogo frente ao modo naturalista de colocar os seus problemas com articulações de meio/personagem, corpo/cultura e natureza/civilização.

\section{Naturalismo, pulsão e desejo}

Embora a estética naturalista possa parecer elástica, sobretudo se considerarmos vertentes e desdobramentos, ela possui limites restritos. Gostaria de salientar um deles, porque reverbera um universo correlato de imagens que vimos no cinema brasileiro dos anos 2000. A sexualidade naturalista é típica de um conceito de pulsão animalesca, pulsão esta que existe em oposição à civilização e à cultura. É como se a cultura fosse um contraponto ao corpo animalesco que, em estado de animalidade, livrado à pureza dos instintos, conduziria necessariamente às violências e à destruição, isto é, ao império da pulsão de morte. Por isso, Deleuze e Guattari (2012) insistem tanto na diferença entre o desejo e a pulsão. 0 desejo traz consigo uma concepção de corpo que não se opõe à cultura, mas está sempre em agenciamentos com ela. A pulsão traz consigo a hipótese de que existe um corpo pré-cultural, um espectro de pura animalidade que se realiza na cultura, mas que 
não é produzido por ela. De modo geral, esse é o conceito do naturalismo. Por isso, o interesse pelas regiões de periferia, onde o autor naturalista julga encontrar os seus personagens longe da civilização e esquecidos em condição de animalidade ${ }^{15}$. 0 diretor de Contra Todos, Roberto Moreira, resume muito bem essa concepção ao falar do filme:

Ao localizar a ação do roteiro em um bairro periférico de São Paulo e escolher como personagens principais matadores, procurei uma situaçãolimite. Nessas regiões a presença do Estado é problemática, senão nula. A violência está completamente incorporada no cotidiano, seja dentro da família, como atestam os inúmeros casos de abuso sexual e incesto, seja nos bares, ponto privilegiado de encontro e chacinas. 0 baixo valor atribuído à vida indica essa sociabilidade primária, ditada por impulsos imediatos e carências inadiáveis. Aqui, o desejo não se sublima em afeto, mas se degrada em gula. Estas são as consequências intersubjetivas da segregação social. Viver à margem embrutece e desumaniza. (MOREIRA, 2010, p. 30).

Logo, isso explica por que um filme como Madame Satã, contemporâneo àqueles aqui analisados, não poderia ser considerado naturalista, embora também se interesse pelo ambiente de periferia, pela sexualidade além dos rigores da civilização, pelo ambiente de cortiços. A sexualidade em Madame Satã é um agenciamento de desejos que não conduz ao fetichismo, às violações e às quedas naturalistas.

Para ilustrar esse argumento, reitero que a sexualidade em filmes naturalistas é dada como um fetiche ou como uma violência. Os realizadores utilizam primeiros planos que recortam o corpo dos personagens e oferecem-no em partes como objeto de fetiche para outros personagens e para os espectadores. É o que acontece com os inúmeros primeiros planos da bunda em $O$ cheiro do ralo e com o primeiro plano da vagina em Amarelo manga. Em suma, a sexualidade nos filmes naturalistas, via de regra, é uma questão de fetichismo com olhar doentio (Baixio das bestas), que produz recortes nos corpos para oferecê-los como objetos para satisfação de um fetiche (Amarelo manga, $O$ cheiro do ralo) e que inúmeras vezes aparece conjugada com um ato de violência (Latitude zero, Baixio das bestas, Contra todos).

Já em Madame Satã, a tônica não é fetichismo, tampouco violação. Na principal cena de sexo no filme, a câmera procura uma mise-en-scène tátil, aproximando-se dos corpos. Não existe recorte dos corpos, nem separação entre um sujeito desejante e um objeto de desejo. A própria câmera parece querer participar e incluir o espectador no ato ao quase tocar os corpos. A câmera move-se continuamente, inibindo a estabilização que formaria um pedaço de corpo ofertado como objeto parcial. 0 fetiche é algo congelado e o contínuo movimento

\footnotetext{
15 Não custa reiterar que esse é apenas um conceito de animalidade, o conceito naturalista, que implica um determinado entendimento das pulsões e sua relação com a pulsão de morte.
} 
da imagem inibe a sua formação. Algo que se destaca, ainda, é que não vemos um centro nas genitálias, como no naturalismo fetichista, mas várias partes de corpos que se montam com as outras ${ }^{16}$.

Figura 5 - Primeiros planos desejantes em Madame Satã
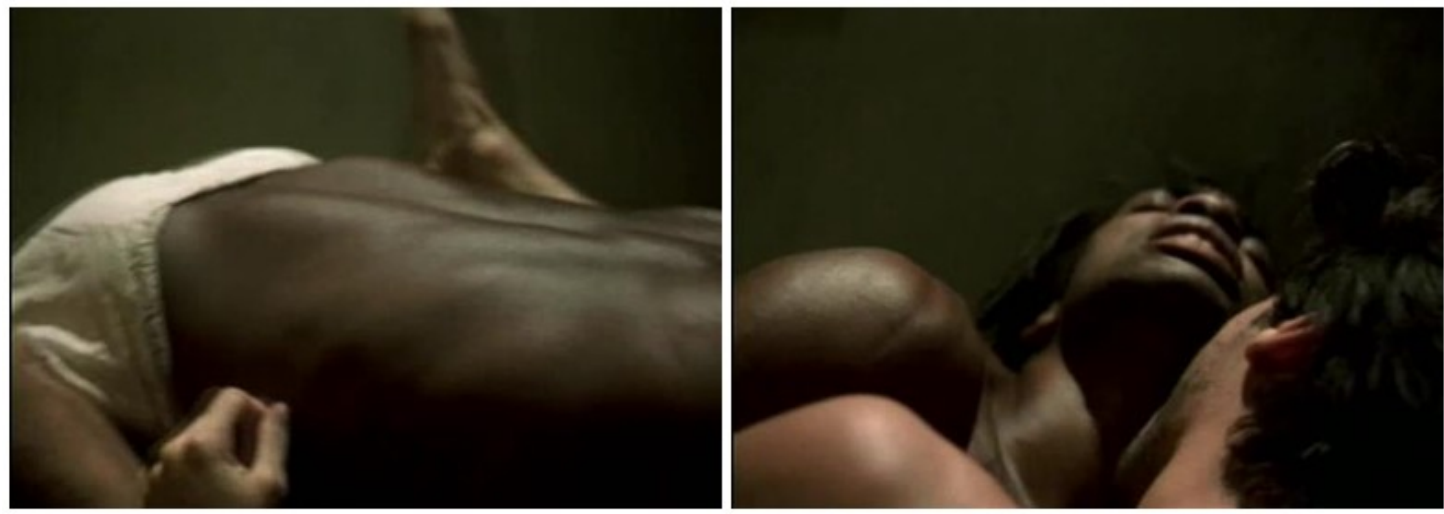

Fonte: Adaptado de Madame Satã (2002).

\section{Sobre o panorama do naturalismo e suas dispersões nos anos 2000}

Olhando de modo panorâmico, veremos que, ao longo da década de 2000, os traços naturalistas vão se dispersando no cinema brasileiro. Os realizadores que mais se interessaram pelas questões de ordem naturalista afastam-se posteriormente. Nesse sentido, é emblemática a avaliação de Beto Brant (2009), quando analisa a sua trajetória após $O$ invasor: "Então há ao mesmo tempo um desencanto. Desencanto dessa descoberta. De que essas relações estão aí, patológicas na sociedade. Pra você não começar a apagar a tua luz, você precisa se reinventar [...] " (BRANT, 2009, doc. não paginado). 0 desencanto era tão intenso que foi preciso procurar outras estéticas, que o realizador desenvolve em Crime delicado (2005). Toni Venturi, Roberto Moreira e Tata Amaral também vão procurar outras influências, com Cabra-cega (2003), Quanto dura o amor? (2009) e Antonia (2006), respectivamente. Inclusive Sérgio Bianchi afasta-se, com Os inquilinos (2009), do projeto que empreendeu em Cronicamente inviável e Quanto vale ou é por quilo?

A trajetória de Cláudio Assis nesse sentido é, mais uma vez, relevante. Seus filmes Amarelo manga e Baixio das bestas são possivelmente os mais naturalistas da década. Depois deles, Assis faz Febre do rato, que também dispersa o naturalismo. 0 naturalismo nos filmes brasileiros foi marcado pela utilização de zonas de invisibilidade como modo de construir plasticamente a escuridão da matéria e a emergência de forças incomensuráveis nos corpos

\footnotetext{
${ }^{16}$ A análise de Febre do rato também revela um conceito de sexualidade desejante que se afasta do naturalismo. (LEITES, 2017, p.102-103)
} 
e no tempo. Cláudio Assis faz isso com o uso dos buracos em Baixio das bestas, com o uso da escuridão no quadro em algumas passagens de Amarelo manga. Em Febre do rato, a zona de invisibilidade atualiza-se como uma banheira que os personagens frequentam para agenciar desejos, fazer sexo, conversar. Altera-se, também, a função da palavra, que passa a ser ativa e capaz de produzir agenciamentos frente aos desígnios dos corpos. 0 contexto discursivo que envolve Amarelo manga, Baixio das bestas e Febre do rato também sofre um deslocamento. Se os filmes naturalistas se justificavam pelo choque e pela "necessidade", nas palavras do realizador Febre do rato é direcionado à juventude e justifica-se porque "É preciso mostrar que cada um pode fazer o que quiser, é só ter coragem [uma vez que, finalmente,] o poeta somos todos nós." (ASSIS ${ }^{17}$ citado por MERTEN, 2012). Erige-se, assim, uma figura que é estranha ao naturalismo, a do poeta com o poder da vontade e do verbo sobre o corpo, o meio e a pulsão de morte.

Desse modo, a observação sobre o naturalismo na década ajuda-nos a compreender um movimento mais geral do cinema brasileiro. 0 cinema brasileiro da década é muito mais amplo do que as atualizações naturalistas que ele comporta. Todavia, pela observação do naturalismo, podemos compreender uma resposta, uma articulação estético-política que parecia adequada no início da década e que foi deixando de ser com o passar dos anos ${ }^{18}$.

\section{Considerações finais sobre imagem e naturalismo}

Em considerações finais, gostaria de sumarizar alguns pontos cruciais acerca da relação entre imagem e naturalismo. Reitero que é absolutamente produtivo pensar o naturalismo em sua relação com a transparência e a mimesis. No entanto, penso que essa análise não deve inibir a problematização sob vieses alternativos, que para mim é uma necessidade advinda da observação das imagens e de uma reavaliação em geral sobre o conceito de naturalismo. Como expus anteriormente, os filmes de Cláudio Assis, Amarelo manga e Baixio das bestas são aqueles que apresentam com maior intensidade as características naturalistas, algo que inclusive foi destacado por críticos e pesquisadores, como Inácio Araújo (2013), Ramayana Lira (2012) e Beatriz Jaguaribe (2007, p. 121-124). Todavia, o naturalismo em Assis vem acompanhado de estratégias de recusa da transparência, como a quebra da quarta parede em ambos os filmes citados e a enunciação verbal de tese sobre o perspectivismo do cinema feita por um personagem em Baixio das

\footnotetext{
${ }^{17}$ Assis no lançamento do filme em Florianópolis, segundo relato de Merten (2012).

${ }^{18}$ Lembrando que, no final dos anos 2000, começamos a falar sobre cinema de afetos, novíssimo cinema brasileiro, cinema de garagem.
} 
bestas $^{19}$. Desse modo, penso que, além de justificado, é necessário tensionar a associação que às vezes parece inequívoca entre imagem, naturalismo e estética da transparência.

Importa considerar, ainda, que o naturalismo não é um projeto datado e circunscrito ao final do século XIX. É verdade que parte de suas premissas soam anacrônicas para o mundo contemporâneo, tais como a defesa da hereditariedade dos vícios, a vinculação ao positivismo da ciência e até a crença na imparcialidade do olhar. Se enxergarmos o naturalismo apenas sob essas características, corremos o risco de convertê-lo em caricatura. Nesse caso, perdemos a oportunidade de compreender suas atualizações em imagens contemporâneas.

A imagem, sendo influenciada pelo naturalismo, comporta uma tese sobre a força da matéria e os excessos do corpo. Como argumentei anteriormente, o naturalismo tem uma visão de oposição entre corpo e cultura, de modo que o corpo é visto como uma esfera de pulsões animalescas, as quais, sem o contraponto suficiente da cultura, cedem ao império da grande pulsão de morte ${ }^{20}$. Por isso, nessas imagens os personagens estão em processo de bestialização e a sexualidade faz parte de um primitivismo tido como decadência e queda de retorno ao inorgânico.

Por todo o exposto, considero que a relação com o naturalismo nos oferece um eixo indispensável para a compreensão da dinâmica do cinema brasileiro nos anos 2000. 0 naturalismo em imagens não deve receber um julgamento moral em si mesmo, isto é, ser descartado ou endossado em bloco. Ele não é bom nem ruim, mas contemporâneo e problemático. 0 naturalismo tem a insistente característica de retornar atualizado como uma das respostas possíveis quando se coloca o problema da arte em relação com os excessos do corpo e a miséria da civilização.

\section{Financiamento}

O autor agradece à Coordenação de Aperfeiçoamento de Pessoal de Nível Superior (Capes) pelo financiamento da pesquisa que originou este texto.

\footnotetext{
19 “Sabe o que que é o melhor do cinema? É que no cinema tu pode fazer o que tu quer." (BAIXIO..., 2006, doc. não paginado).

20 "Parece-me que a questão decisiva da espécie humana é a de saber se, e em que medida, o seu desenvolvimento cultural será bem-sucedido em dominar o obstáculo à convivência representado pelos impulsos humanos de agressão e de autoaniquilação." (FREUD, 2013, p. 184).
} 


\section{Referências}

ABREU, Luis; AMARAL, Tata; BERNARDET, Jean-Claude; XAVIER, Ismail. Cinema e tragédia. Estudos de Cinema, São Paulo, n.2, p. 69-99, 1999. Compilação com as falas dos autores em evento promovido pelo CEC na PUC/SP.

ANTONIA. Direção: Tata Amaral. Produção: Geórgia Araújo, Georgia Amaral, Tata Amaral. São Paulo: Coração da Selva, 2006. 1 DVD (90 min), son., color.

AQUINO, Marçal. [Depoimento durante entrevista de Beto Brant]. In: SALA DE CINEMA. Direção artística e apresentação: Miguel de Almeida. Direção e roteiro: Luiz R. Cabral. São Paulo: Sesc TV, 2009.

ARAÚJO, Inácio. Crítica: Cláudio Assis acha equilíbrio no filme "Baixio das Bestas". Folha de São Paulo, São Paulo, 18 maio 2013.

ÁRIDO movie. Direção: Lírio Ferreira. Produção: Lírio Ferreira, Murilo Salles. Pernambuco: Cinema Brasil Digital, 2005. 1 DVD (115 min), son., color.

AUMONT, Jacques; MARIE, Michel. Dicionário teórico e crítico de cinema. Campinas: Papirus, 2003.

ASSIS, Cláudio. Entrevista com Claudio Assis. [Entrevista concedida a] Cléber Eduardo. Contracampo: revista de cinema, [s.l.], 2003.

ASSIS, Cláudio. Sala de Cinema: Cláudio Assis. In: SALA DE CINEMA. Direção artística e apresentação: Miguel de Almeida. Direção e roteiro: Luiz R. Cabral. São Paulo: Sesc TV, 2011a. 49min.

ASSIS, Cláudio. Cláudio Assis continua indomável. [Entrevista concedida a] Julio Bezerra. Revista de cinema, São Paulo, 15 dez. 2011b.

BAGULEY, David. Naturalist fiction: the entropic vision. Cambridge: Cambridge University Press, 1990.

BAIXIO das bestas. Direção: Cláudio Assis. Produção: Cláudio Assis, Júlia Moraes e Julia de Morais. Pernambuco: Parabólica Brasil, Quanta Centro de Produções Cinematográficas, Rec Produtores Associados Ltda, 2006. 1 DVD (80 min), son., color.

BAZIN, André. What is cinema? Los Angeles: University California Press, 1971. v. 2.

BECKER, Colette. Lire le réalisme et le naturalisme. Paris: Dunod, 2010.

BRANT, Beto. Entrevistado: Beto Brant. In: In: SALA DE CINEMA. Direção artística e apresentação: Miguel de Almeida. Direção e roteiro: Luiz R. Cabral. São Paulo: Sesc TV, 2009.

CABRA-CEGA. Direção: Toni Venturi. Produção: Toni Venturi. São Paulo: Olhar Imaginário Ltda., 2003. 1 DVD (105 min), son., color.

CHEVREL, Yves. Le naturalisme: étude d'un movement littéraire international. Paris: PUF, 1993. 
CHIARA, Ana Cristina. Em carne viva: a hiperfísica de Santiago Nazarian e Valêncio Xavier. In: IMÁGENES Y REALISMOS EN AMÉRICA LATINA, SIMPOSIO INTERNACIONAL, 2011, Leiden. Actas [...] Leiden, 2012.

CRIME delicado. Direção: Beto Brant. Produção: Bianca Billar. Renato Ciasca, Marco Ricca. São Paulo: Drama Filmes, MG Ricca, Eba Filmes International; Brasil Filmes, 2005. 1 DVD (87 min), son., color.

CRONICAMENTE inviável. Direção: Sérgio Bianchi. Produção: Sérgio Bianchi, Gustavo Steinberg e Alvarina Souza e Silva. São Paulo: Agravo Produções Cinematográficas, 2000. 1 DVD (101 min), son., color.

DELEUZE, Gilles. A imagem-movimento. São Paulo: Brasiliense, 1985.

DELEUZE, Gilles. Lógica da sensação. Rio de Janeiro: Jorge Zahar, 2007.

DELEUZE, Gilles; GUATTARI, Félix. Mil platôs: capitalismo e esquizofrenia 2. Rio de Janeiro: Editora 34, 2012. v. 3.

DESERTO feliz. Direção: Paulo Caldas. Produção: Germano Coelho Filho. Pernambuco: Camará Filmes Ltda., 2007. 1 DVD (88 min), son., color.

FEBRE do rato. Direção: Cláudio Assis. Produção: Cláudio Assis; Julia Maia; Marcelo Ludwig. Rio de Janeiro: Polo de Imagem; Belavista Cinema e Produção; Parabólica Brasil; República Pureza Filmes; Perdidas Ilusões, 2011. 1 DVD (105min), son., PB.

GUINSBURG, Jacó; FARIA, João Roberto (org.). O naturalismo. São Paulo: Perspectiva, 2017. HUYSMANS, Joris-Karl. Às avessas. São Paulo: Penguin, 2011.

JAGUARIBE, Beatriz. 0 choque do real: estética, mídia e cultura. Rio de Janeiro: Rocco, 2007.

JAMESON, Fredric. The antinomies of realism. London: Verso, 2015.

LATITUDE Zero. Direção: Toni Venturi. Roteiro: Di Moretti. Brasil: Olhar Imaginário, 2000. 1 DVD (85 min), son., color.

LEITES, Bruno. Quando a imagem faz sintoma: imagem-pulsão e neonaturalismo no cinema brasileiro dos anos 2000. 2017. Tese (Doutorado em Comunicação e Informação) Programa de Pós-Graduação em Comunicação e Informação, Universidade Federal do Rio Grande do Sul, Porto Alegre.

LIRA, Ramayana. Rio, pontes e overdrives: trânsito e a (de)composição do espaço em Amarelo Manga. Crítica Cultural, Palhoça, v. 7, n. 1, p. 149-157, jan./jun. 2012.

MADAME Satã. Direção: Karim Ainouz. Produção: Isabel Diegues, Maurício Ramos, Walter Salles, Marc Beauchamps,Donald K Ranvaud, Vincent Maraval e Juliette Renaud. Rio de Janeiro: VideoFilmes, 2002. 1 DVD (105 min), son., color. 
MENDES, Leonardo; VIEIRA, Renata. Epopeia da impotência humana: naturalismo, desilusão e banalidade no romance brasileiro do final do século XIX. E-scrita, Nilópolis, v. 3, n. 3, p. 139-152, 2012.

MERTEN, Luiz Carlos. Diretor fez "Febre do rato" para provar aos jovens que poeta é quem ousa. Estadão, São Paulo, 22 jun. 2012.

MOREIRA, Roberto. Como fiz Contra Todos. Olhares, São Paulo, v. 1, n. 2, p. 28-49, jul./dez. 2010.

NAGIB, Lúcia. A utopia no cinema brasileiro: matrizes, nostalgias, distopias. São Paulo: Cosac Naify, 2006.

NEWLIN, Keith. Introduction: the naturalistic imagination and the aesthetics of excess. In: NEWLIN, Keith (org.). The Oxford handbook of american literary naturalism. New York: Oxford University Press, 2011a.

NEWLIN, Keith (org.). The Oxford handbook of american literary naturalism. New York: Oxford University Press, 2011b.

OS INQUILINOS. Direção: Sérgio Bianchi. Produção: Sérgio Bianchi. São Paulo: Agravo Produções Cinematográficas, 2009. 1 DVD (103 min), son., color.

PHILLIPS, Gene. Out of the Shadows: expanding the canon of classic film noir. Maryland: Scarecrow Press, 2012.

QUANTO dura o amor? Direção: Roberto Moreira: Produção: Geórgia Araújo. São Paulo: Coração da Selva Transmídia, 2009. 1 DVD (83 min), son., color.

RANCIÈRE, Jacques. A partilha do sensível: estética e política. São Paulo: EXO Experimental, 2005.

RANCIÈRE, Jacques. 0 inconsciente estético. São Paulo: Editora 34, 2009.

SANTOS, Antonio Carlos. 0 naturalismo sob o olhar modernista: Candido e a crítica a Aluísio Azevedo. Crítica Cultural (Critic), Palhoça, v. 6, n. 2, p. 557-563, jul./dez. 2011

SCHØLLHAMMER, Karl Erik. Cena do crime: violência e realismo no Brasil contemporâneo. Rio de Janeiro: Civilização brasileira, 2013.

STAM, Robert. Introdução à teoria do cinema. Campinas: Papirus, 2013.

XAVIER, Ismail. 0 discurso cinematográfico: a opacidade e a transparência. São Paulo: Paz e Terra, 2005.

ZOLA, Émile. Le roman expérimental. Paris: Nouveau Monde Éditions, 2004. 


\title{
Naturalism and its dispersions in 2000s Brazilian films
}

\begin{abstract}
The literary Naturalism is an aesthetic frequently repulsed in analyses of Naturalism and Realism in the cinema. In this work, I take an alternative course, recovering the characteristics of Naturalism to analyse a wave of films in the 2000s Brazilian cinema. Over the decade, a series of films has actualized the characteristics of the Naturalist project, among which I highlight the objective of making studies of peripheral realities exhausted by the crises of civilization; the searching for diseases deeply rooted in those regions; the presence of the tragic, the entropy and/or the death instinct; an aesthetics of excess with cruelty, sensation and sensationalism. Those characteristics got together in Naturalist films, however, they were dispersed in the decade, showing that Naturalist premises were no longer attractive as an aesthetical and political project over the years. Finally, I defend the pertinence and necessity of placing the problem of image and Naturalism beyond the extreme and caricatured submission to the paradigm of transparency.
\end{abstract}

\section{Keywords}

Naturalism. Image. Brazilian cinema. Literature. Death drive.

Recebido em 05/09/2018

Aceito em 13/11/2018 